\title{
Farming in and on urban buildings: Present practice and specific novelties of Zero-Acreage Farming (ZFarming)
}

\author{
Susanne Thomaier ${ }^{1 *}$, Kathrin Specht ${ }^{2}$, Dietrich Henckel ${ }^{1}$, Axel Dierich ${ }^{3}$, Rosemarie Siebert ${ }^{2}$, \\ Ulf B. Freisinger ${ }^{4}$ and Magdalena Sawicka ${ }^{2}$ \\ ${ }^{1}$ Technische Universität Berlin, Department for Urban and Regional Economics, Berlin, Germany. \\ ${ }^{2}$ Institute of Socio-Economics, Leibniz Centre for Agricultural Landscape Research, Leibniz, Germany. \\ ${ }^{3}$ inter 3 Institute for Resource Management, Berlin, Germany. \\ ${ }^{4}$ Freie Universität Berlin, Executive Board, Berlin, Germany. \\ ${ }^{*}$ Corresponding author: s.thomaier@isr.tu-berlin.de
}

Accepted 12 March 2014;

First published online 24 April 2014

Preliminary Report for Themed Content: Urban Agriculture

\begin{abstract}
Considering global trends such as climate change and resource scarcity, a major challenge of future cities will be to reduce urban footprints. Moreover, cities have to become or remain livable for their inhabitants and offer social and economic opportunities. Thus, reconnecting food production and cities offers promising potential. The diffusion of urban farming reflects a rising awareness of how food and farming can shape our cities. A growing number of urban farming projects exist in and on urban buildings, including open rooftop farms, rooftop greenhouses and indoor farming. These projects are characterized by the non-use of land or acreage for farming activities. We use the term 'Zero-Acreage Farming' (ZFarming) to represent these farms. The objective of this paper is to: (1) illustrate and systemize present practices of ZFarming and (2) discuss specific novelties of ZFarming in the wider context of urban agriculture. We analyzed 73 ZFarms in cities of North America, Asia, Australia and Europe using a set of criteria, and developed a typology of ZFarming, complemented by in-depth interviews with pioneers in rooftop farming in New York. The results illustrate that ZFarming generates innovative practices that may contribute to a sustainable urban agriculture. Besides growing food, it produces a range of non-food and non-market goods. It involves new opportunities for resource efficiency, new farming technologies, specific implementation processes and networks, new patterns of food supply and new urban spaces.
\end{abstract}

Key words: urban farming, urban innovation, rooftop farming, indoor farming, rooftop greenhouse, building integrated, ZeroAcreage Farming, sustainability

\section{Introduction}

Supplying urban areas with energy, water, space and food strongly relies on flows of external resources into cities: 'Cities occupy only 2 per cent of the world's surface, but they consume 75 per cent of its resources' ${ }^{1}$. At the same time, cities are ecologically more efficient than any other type of settlement ${ }^{2,3}$. Considering global trends, such as climate change and resource scarcity, new approaches are needed to reduce urban footprints and make cities sustainable. The question of how to feed future cities is a central issue in this context. The spatial distance between the people and the agricultural land that supports them alters ecosystems because it prevents nutrient recycling and creates high costs and emission problems of long-distance transport ${ }^{3,4}$. Steel ${ }^{5}$ highlights that, 'what is clear is that the relationship between non-foodproducing communities (aka cities) and food-producing ones (aka countryside) is dangerously out of kilter'. She also stresses the need to put food back on the cities' agenda, calling for a major cultural shift with new political and economic structures, planning models and social order". Moreover, we need to 'mitigate the harmful impact of urban development on the natural environment, whilst also maximizing design quality and livability, economic growth, cultural diversity and social prosperity to bring just and healthy urban developments ${ }^{6}$. Several authors emphasize that the reintegration of food and cities offer opportunities to address these challenges $^{7,8}$. 
Urban farming is largely driven by the desire to reconnect food production and consumption. The diffusion of urban farming reflects an increasing awareness of how food and farming can shape our cities. During the past 5 years a new phenomenon in urban agriculture has evolved. A growing number of urban farming projects are being established in and on existing buildings, using rooftop spaces or abandoned buildings. In discussions, we find different images and definitions of this phenomenon, demonstrating that there is no common understanding of these practices.

Often the images are associated with futuristic multilevel vertical farms - sophisticated, built, urban structures that solely serve as spaces for agrifood business to cultivate high yields of food within skyscrapers or on vertically inclined surfaces in a technologically advanced manner'. So-called 'vertical farms' represent the most farreaching vision of farming in and on urban buildings. Another approach is building-integrated agriculture, i.e., greenhouse systems on buildings, to exploit synergies between buildings and agriculture ${ }^{10}$. At the opposite end of the spectrum, there are open, soil-based rooftop farming projects that often employ less sophisticated growing methods.

Our perspective embraces all forms of food production related to urban buildings, including open rooftop farms, rooftop greenhouses, productive facades and indoor farming on and in existing or newly built urban structures. The farming can be soil-based or hydroponic and may also involve livestock. It can take place in mixed-use or single-farming-use buildings. Since these specific forms of food production are characterized by the non-use of land or acreage, we use the term 'Zero-Acreage Farming' (ZFarming) to represent them ${ }^{11}$. Of course, some of the principles of ground-based urban farming also apply to ZFarming. However, using the urban building stock instead of farmland or vacant parcels and brownfields, ZFarming differs from ground-based urban farming in ways that present distinct opportunities and challenges. ZFarming can be understood as a subtype of urban farming that complements ground-based forms but implies specific technical restraints, regulatory frameworks and opportunities for resource-efficiency based on synergies between buildings and farming.

There is a lack of comprehensive empirical studies exploring the status quo of ZFarming in all its different forms and functions. Existing empirical studies mostly focus on single cases or one specific form of ZFarming ${ }^{9,12-15}$. Specht et al. ${ }^{11}$ offer a profound review of the literature on ZFarming, but no empirical evidence on current practices.

The objective of this contribution is to:

(1) illustrate and systemize current ZFarming practices, considering different forms, functions, players, underlying principles and procedural mechanisms;

(2) create a typology of ZFarming in order to structure the diversity of ZFarming; and
(3) discuss specific novelties inherent to ZFarming in the wider context of urban agriculture.

\section{Methodology and Empirical Basis}

For analyzing and assessing current ZFarming practices, a qualitative four-step approach was chosen:

(1) Identifying existing ZFarming projects: Intensive web, media and literature research in 2011 and 2012 resulted in a total of 73 identified projects in North America (44), Europe (19), Asia (15) and Australia (1). Given our focus on the role of ZFarming in developed countries, research was limited to Europe, North America and parts of Asia, i.e., Asian economies with upper-middle-income levels (according to World Bank definitions) ${ }^{16}$. While the list is by no means complete or statistically representative, it does serve the purpose of providing a broad overview of present ZFarming practices.

(2) Developing research criteria for the analysis: Research criteria were derived from literature review and 20 explorative interviews conducted with practitioners and researchers at early stages of the research. Selected criteria presented in this paper include: strategic orientation of ZFarming projects; spaces used; spatial diversification; farming methods; ZFarming products and activities; market orientation; financing; and planning and implementation processes. Websites and relevant contributions in the literature and the media were investigated accordingly. Although information, due to our reliance on publicly accessible data, could not always be retrieved for all of the criteria, it still allowed for a comprehensive picture regarding present ZFarming.

(3) Creating a ZFarming typology: ZFarms greatly vary in form, function and players. The typology helps to understand different ZFarming strategies and underlying principles and to develop reference points for theorizing. It is based on the criteria of 'market orientation' and 'strategic orientation', i.e., economic dimensions and broader goals.

(4) In-depth interviews: Seven in-depth interviews with pioneers in rooftop farming in New York City were conducted. The interviews addressed questions that could not be clarified by desk-research (e.g., planning and implementation processes, financing) and served to substantiate the typology. Interviewees included ZFarming operators (private entrepreneurs and nonprofit organizations); and public, private and nonprofit landlords or real-estate developers. Interviews were focused on New York City because it has the greatest variety of ZFarming, enabling us to contact actors from a wide range of sites. While we are aware of a possible bias due to this one-city focus, the interviews substantially complement the 


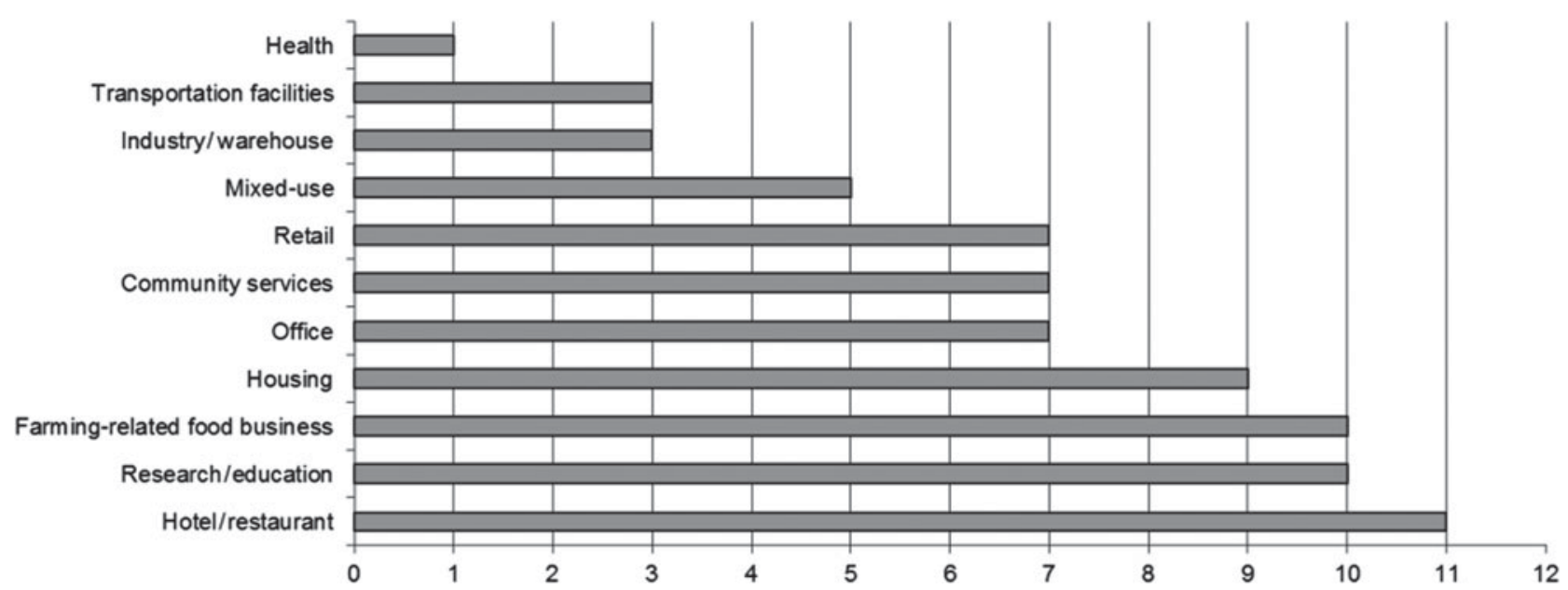

Figure 1. Building uses combined with ZFarming (absolute frequencies, $n=73$ ).

desk-research analysis and add to the general understanding of ZFarming.

\section{Results: Present Practices of ZFarming Strategic orientation of ZFarms}

There are a great variety of purposes associated with ZFarming. Even though each farm has specific goals, three main categories of strategic orientations are observed that differ in their potential to transform existing mechanisms in the agrifood system (cf. Stevenson et al. ${ }^{17}$ in a different context):

- Sustainable food production (high transformative potential): ZFarming is used to create sustainable models of food supply, focusing on food production and alternative supply chains. It may include research for new solutions for food production, experimenting with synergies between buildings and farming.

- Education and social commitment (medium transformative potential): ZFarming is used as a means of teaching values associated with local and sustainable food production and healthy nutrition, or of offering new opportunities of social integration, e.g., for disadvantaged people.

- Urban qualities (low transformative potential): ZFarming is seen as a 'productive', but primarily recreational space that improves urban qualities and contributes to the social life or even the image of a community.

\section{Spaces used for ZFarming}

Most of the identified ZFarms use rooftops, but there is also an increasing number of indoor ZFarms using one or more floors within buildings (Table 1).

In most cases, ZFarming is integrated into existing mixed-use buildings (Fig. 1). No buildings specifically
Table 1. Different forms of ZFarming (absolute frequencies, $n=73$ ).

\begin{tabular}{lcc}
\hline & $\begin{array}{c}\text { Absolute frequencies } \\
(\boldsymbol{n}=\mathbf{7 3})\end{array}$ & Percentages \\
\hline Rooftop farm/garden & 47 & 64.4 \\
Indoor farm & 17 & 23.3 \\
Rooftop greenhouse & 6 & 8.2 \\
Façade & 1 & 1.4 \\
Other & 2 & 2.7 \\
\hline
\end{tabular}

constructed for growing food were found. Rather, some indoor farmers redevelop abandoned buildings.

In specific contexts, ZFarming may directly relate to and interact with other uses in a building: schools using greenhouses as green classrooms; community rooftop gardens serving as recreational spaces for residents; restaurants using produce from their own rooftop farm. In other cases, no such interaction is found.

\section{Spatial diversification}

Spatial distribution of ZFarming reveals clusters as well as regional characteristics. North America has the largest number of ZFarms (44), followed by Europe (19), Asia (15) and Australia (1). Almost all identified ZFarms were located in cities with more than 150,000 inhabitants. In North America, clusters are in New York City (18 ZFarms), Chicago (9) and Toronto (5). In Europe and Asia, the numbers are generally too low to speak of clusters. However, there are slight concentrations in Tokyo (6) and Hong Kong (4). ZFarming characteristics in our sample tend to differ among regions. Technically sophisticated rooftop greenhouses seem to be mostly a North American phenomenon. Regarding ZFarming goals, North America and Europe have the greatest share of farms oriented to sustainable food production, while in very dense Asian cities, such as Tokyo and Hong Kong, the focus seems to be on enhancing urban qualities. 
Table 2. Applied farming methods (absolute frequencies, $n=73)$.

\begin{tabular}{lcc}
\hline & $\begin{array}{c}\text { Absolute frequencies } \\
(\boldsymbol{n}=\mathbf{7 3})\end{array}$ & Percentages \\
\hline Soil-based & 51 & 69.9 \\
Hydroponics & 10 & 13.7 \\
Mixed & 9 & 12.3 \\
Aquaponics & 3 & 4.1 \\
\hline
\end{tabular}

However, the small size of our sample - especially for Europe and Asia - hardly allows for general conclusions.

\section{Farming methods}

Most projects employ soil-based methods - soil placed either directly on the rooftop (greenroof technology) or in raised-beds or mobile containers. Some use hydroponics, and a few use aquaponic systems that combine vegetable and fish farming (Table 2). Hydroponics is applied in both indoor farming and rooftop greenhouses, aquaponics only in indoor farming. Most of the farms, being outdoor facilities, grow seasonally. Farms with year-round production use either greenhouses or operate indoors. Even though all farms claim to grow without pesticides, only a few are certified as organic. One reason may be that many ZFarms do not produce for the market, so there is no need for certification. Also, given the very complex and costly procedures, small-scale farmers may be deterred from applying for organic certification ${ }^{18,19}$. Finally, soil-less growing systems such as hydroponics are often not yet eligible for organic certification.

\section{ZFarming products and activities}

ZFarms produce various vegetables and fruits, but usually no cereals. For perishable fruits and vegetables, the benefits of being close to consumers are considerable. Commercial ZFarms focus on produce with a high turnover or 'forgotten' cultivars. Indoor farms mostly grow leafy produce. Some ZFarms use bees for honey and pollination, chickens for egg production and fish for aquaponics.

Many ZFarms offer non-food products and activities, such as internships or educational programs, including tours and workshops on food and nutrition for school classes and the community. Some offer cultural programs, involve residents as volunteers, operate their own shops or provide consulting services for ZFarming. ZFarming businesses may also include the packaging, processing and distribution of their produce.

The (re)use of local resources is mostly limited to collecting rainwater and composting, with compost used to refertilize the soil. Some ZFarms use energetic synergies between farming and buildings: the rooftop greenhouse on Eli Zabar's Vinegar Factory (New York) uses the waste heat of a bakery for heating; in The Plant (Chicago), food waste composted by an anaerobic digester and creating the power for a combined heat and power system is used for food production; the Maison Productive (Montréal) uses the building's graywater to supplement rainwater for irrigation.

\section{Market orientation}

In most cases, produce from ZFarms is meant for private use rather than for the market, or is processed, cooked and/or sold to another business in the same building, usually run by the farm's operator (e.g., a restaurant with a kitchen garden managed by the chef). Some commercial ZFarms produce for local urban markets. Fresh or processed products are sold through on-site vending, farmers markets, community-supported agriculture or direct distribution to local restaurants and supermarkets. Some ZFarms cooperate with regional farmers to increase product variety and use common marketing and distribution channels. Commercial ZFarmers compete on the basis of quality rather than price.

\section{Financing}

Interviewees stressed that financing is a key challenge for many ZFarms. The main sources of financing, sometimes combined depending on the respective ZFarming concept, are:

- Investors, mostly for large-scale and technically sophisticated commercial projects.

- Crowdfunding and donations, particularly for community-oriented projects.

- Community-supported agriculture, for commercial projects.

- Grants, addressing environmental (e.g., stormwater retention), social (e.g., education, integration) or spatial (e.g., redevelopment) issues.

- Voluntary work, a critical source of 'capital', since it considerably reduces the need for monetary resources.

\section{Planning and implementation processes}

ZFarming planning and implementation processes often involve a wide range of parties, such as project initiators, landlords, planning and engineering specialists, financing institutions and investors, city administration, neighbors, market institutions, science, support organizations and the media. Interviewees also reported problems in the planning and implementation processes due to lack of practical ZFarming experience. Specific challenges are:

- Suitability of the building: size of available space for growing and other activities, weight-bearing capacity, accessibility, logistics and infrastructure (e.g., freight elevator, water, energy), and the need for retrofitting;

- Zoning and building regulations, permission processes: floor-to-area ratios, maximum allowable building heights, commercial farming as urban land-use, fire and energy codes, etc.; 


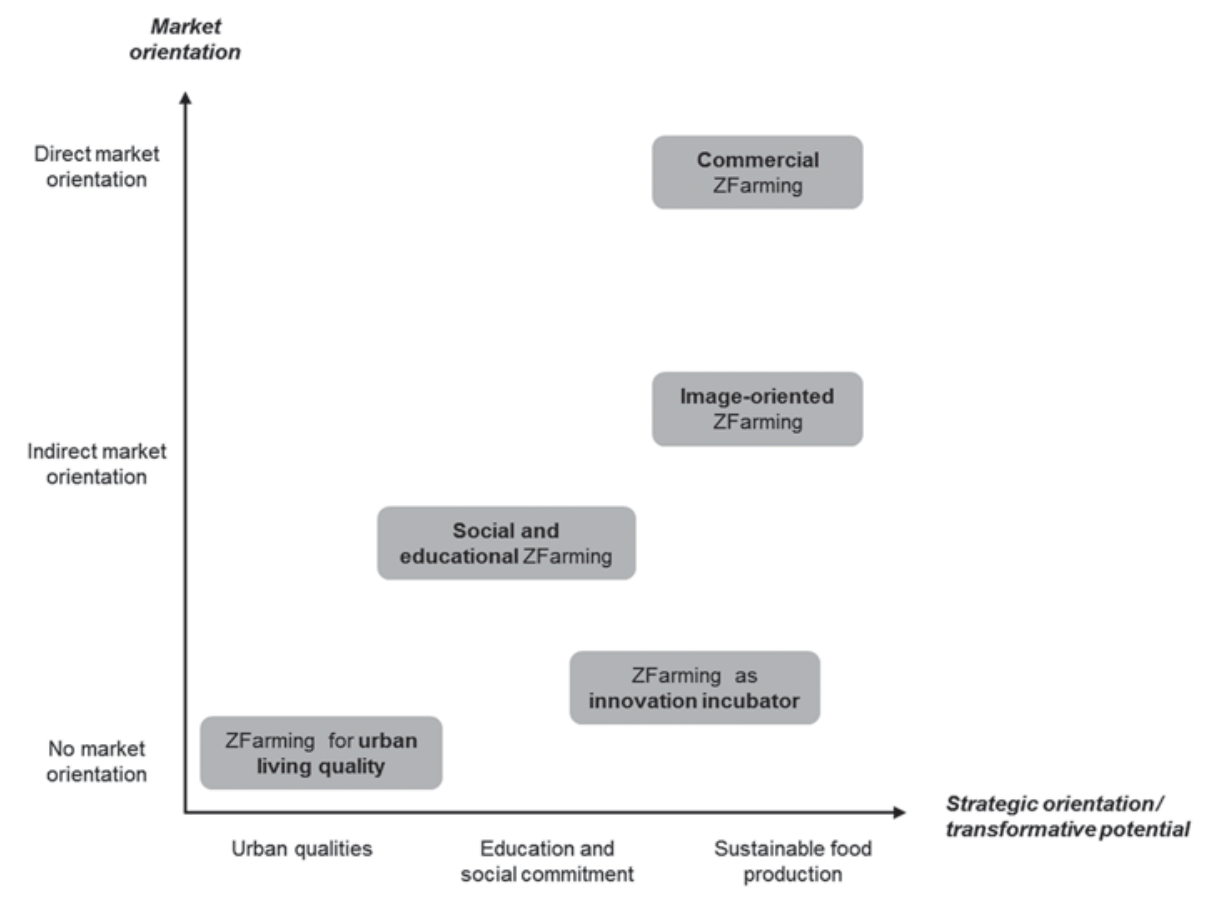

Figure 2. ZFarming typology.

- Support by landlords;

- Financing; and

- Technical issues.

Interviewees emphasized the necessity of early exchange and communication, particularly between initiators, landlords, engineers and public administrators.

\section{ZFarming typology}

Figure 2 shows the five ZFarming types that can be identified along the two scales, i.e., the two criteria used for the typology.

While ZFarms can be classified according to this typology, overlaps may occur. Cohen et al. ${ }^{20}$ note that projects 'also share many similar goals and practices, blurring simple boundaries. A for-profit, commercial farm, for instance, may also run a nonprofit arm [...]. Both nonprofits managing farms and community gardeners sell produce [...], allowing people to earn income from what they grow and generating revenue to support programming.'

\section{Commercial ZFarming (14 out of 73)}

The main purpose of commercial ZFarms is to run an economically viable farming business, usually operated by a start-up, based on an either 'retail-affiliated' or 'independent' business model. 'Retail-affiliated' ZFarms primarily cooperate with one specific retailer. Two variants can be identified: agricultural production is initiated, implemented and operated by either the retailer on-site (e.g., rooftop greenhouse on a grocery store), or by a farming business that is bound by contract to one specific retailer. 'Independent' commercial ZFarms do not collaborate with one specific retailer but rather use various distribution channels. Both 'retail-affiliated' and 'independent' ZFarm operations may include processing and packaging. Whereas 'retail-affiliated' commercial ZFarms focus solely on food business, 'independent' commercial ZFarms may be community-oriented and open to the public.

All kinds of ZFarms can be operated commercially, given a minimum size for economic viability. Suitable spaces are mainly on or in commercial, industrial or manufacturing sites. Farming techniques include soilbased as well as more efficient forms such as hydroponics or aquaponics.

\section{Image-oriented ZFarming (18 out of 73)}

In this case, ZFarming is not the main source of revenue but serves as an 'add-on' to other food businesses (e.g., restaurants, cafeterias) that process, cook and sell the ZFarming produce. The image served is to offer highquality, fresh and local produce and to be sustainable and innovative. Given the purpose of enhancing the main business, farming itself is not necessarily profitoriented. Thus, image-oriented ZFarms are mostly integrated as small-scale rooftop or indoor farms in the building of the main business and may provide limited access to the public (e.g., at certain times or by offering public tours). Farming techniques are mostly soil-based, with only a few image-oriented ZFarms employing hydroponics. 


\section{Social and educational ZFarming (20 out of 73)}

The main purpose of these ZFarms is to communicate social and educational values. They are found at schools, universities and other public, private and non-profit educational or social institutions. Their produce is either for personal use by the people involved or for an affiliated cafeteria or market. Farms are community-oriented and serve as showcases for environmental education and sustainable and healthy food production. They often involve voluntary work by local residents. Spaces used are mainly on the rooftops of the affiliated institutions. Farming techniques are mostly soil-based, with only a few using hydroponics or aquaponics.

\section{ZFarming for urban living quality (15 out of 73)}

In this case, ZFarming is used for enhancing urban qualities. ZFarms on residential, commercial or mixeduse buildings serve as recreational spaces where residents or employees can grow their own food and enjoy a green oasis close to their homes or workplaces. The idea of traditional green roofs is pushed one step further by combining it with urban food growing. Farms are initiated either by real estate developers keen on upgrading their site and capitalizing on the idea of a green, sustainable and livable building, or by businesses that want to improve their employees' working environment. Since 'digging in the soil' is a key idea, these projects are usually soil based. The produce is mostly for personal use, and sometimes for use by an affiliated cafeteria.

\section{ZFarming as innovation incubator (6 out of 73)}

Several ZFarms serve the purpose of promoting new concepts of food production and sustainable ways of organizing urban life and consumption. They often are pioneer or demonstration projects operated by non-profit organizations or research institutions. Some of these innovation incubator projects are not located in or on normal buildings but use special forms, e.g., boats reproducing a building's environment for research purposes, modular designs (such as containers) that can be integrated into different built forms, or even ground-based greenhouses for testing growing components for use in a built environment. A substantial number of these ZFarms use hydroponics or aquaponics. To promote their innovative concepts they often provide access to the public, e.g., tours or educational/environmental programs.

\section{Discussion: The Contribution of ZFarming to Sustainable Urban Agriculture}

\section{New opportunities for resource efficiency}

Integrating agricultural production into urban buildings offers various opportunities for saving and recycling natural resources, mainly water, energy and organic waste.

Concerning water, the analysis has shown that many ZFarms harvest rainwater, thus helping to delay and reduce urban stormwater run-off. Hydroponics, which is increasingly applied by commercial ZFarming projects, allows for considerable water savings compared to conventional farming. According to Caplow, each hectare of a recirculating rooftop vegetable greenhouse would save 75,000 tons of fresh water per year ${ }^{10}$. Astee and Kishnani ${ }^{21}$ show that for the same yields of vegetables, rooftop gardens using hydroponics need $75 \%$ less water than conventional farms. Water consumption can also be reduced by using the building's graywater for irrigation.

Concerning energy, ZFarming offers various innovative solutions for improving a building's energy efficiency. Many ZFarms are open rooftop farms that generate green-roof effects: they reduce summer cooling load and rooftop surface temperatures, insulate against cold, and reduce heat $\operatorname{losses}^{22,23}$. Vertical rooftop gardens have the same effects: a Canadian study states that '[Green roofs as well as vertical rooftop gardens] reduced surface temperatures sufficiently to suggest that significant reductions of the urban heat island would be attainable if these technologies were adopted on a widespread basis ${ }^{22}$. Rooftop greenhouses may even function as cooling, heating and energy recycling plants ${ }^{11}$, providing insulation, thus minimizing heat gains and losses through roofs $^{24}$, or using the building's waste heat for heating-a reason why buildings with heat-exhausting uses are suitable sites for rooftop greenhouses. However, another inventive approach is greenhouse use for energy generation: excess heat from solar gains in the greenhouse can be fed into the building's heating system ${ }^{24,25}$. This practice, however, is not yet widespread.

Many ZFarms use organic waste for composting. A study on open rooftop farms shows that 'compost is an essential soil-building component for each project', even though it requires extra space, which might be challenging for rooftop farms ${ }^{26}$. Aquaponics, used by some indoor farms, represents a specific type of nutrient recycling. It combines hydroponic horticulture and fish farming by using fish excretions as nutrients for plants in closed water cycles $^{27}$. Studies show that aquaponics allows for highly water-efficient fish farming systems ${ }^{28}$.

\section{New farming methods}

Farming technologies range from low-tech to high-tech. While open, soil-based rooftop farms operate with existing green roof technologies or standard raised beds, rooftop greenhouses and indoor farms require more sophisticated solutions. ZFarms often use proven technologies of industrial (rural) farming or green roof industries. Implementing these techniques in novel settings (urban rooftops, vacant buildings) and circumstances (creating 'edible' green roofs) both require and 
spur technical progress. Each new ZFarm enhances the specific technological and architectural know-how. Moreover, high-tech commercial ZFarming often involves high investment and operating costs (e.g., energy cost for indoor farming), thus putting pressure on ZFarming pioneers to seek maximum efficiency in terms of yields and energy and water savings. This pressure for efficiency encourages technical innovations, such as space-saving vertical hydroponic growing elements or highly specialized plant growing lights for indoor growing.

Synergies between farming and buildings are not yet fully exploited, probably because most ZFarms are integrated into existing buildings. Existing building infrastructures are not necessarily compatible with the implementation of energy loops or other resource-efficient systems. This highly complex challenge spurs new technical solutions in infrastructure planning, architecture, farming and various other disciplines ${ }^{14}$.

One critical aspect of ground-based urban farming is the high level of air pollutants in urban settings, which may lead to crop contamination and health risks ${ }^{29,30}$. Since indoor farms and rooftop greenhouses operate in a controlled environment, ZFarming may reduce these risks. Furthermore, rooftop farms are farther away from roads than ground-based farms or allotments. Studies suggest that the presence of barriers between crop cultivation and roads reduces contamination risks ${ }^{29}$. However, there are no studies on the actual contamination of ZFarming crops in comparison with produce from ground-based urban farming.

\section{New patterns of food supply}

Even if the list of existing ZFarms is by no means complete, it is still obvious - given the sheer numbersthat ground-based urban farming contributes more to food provision than ZFarming. In New York City, for example, $18 \mathrm{ZFarms}$ (of all the five types) were identified versus more than 1000 ground-based community gardens, with more than $80 \%$ of them growing food, and between 15 and 30 farms (the exact number depends on the definition of 'farm'; for the difficulties of distinguishing community gardens from farms; see Ackerman ${ }^{31}$ ). Thus, to date, ground-based urban farming certainly offers broader access to fresh-grown food for urbanites. But assuming further expansion of commercial, high-yield ZFarming activities, and considering future resource scarcity in growing urban areas, ZFarming seems promising and, moreover, relevant for future urban food provision $91,13,21,22,24$.

That said, the role of ZFarming in urban food supply differs between developed and developing countries. In developing countries, small-scale subsistence rooftop gardening plays an important role in feeding families or small communities and helping them to survive in cities ${ }^{32}$. In developed countries, the issue of food security is especially relevant for low-income neighborhoods that lack retail facilities offering fresh and healthy food ('food deserts' $)^{7}$. ZFarming, as a subtype of urban farming, could play an important role in improving access to fresh produce in these areas. However, only very few of the identified ZFarms explicitly focus on supporting and feeding low-income people. The characteristics of ZFarming locations in New York City and Chicago (the main clusters of our sample) seem to confirm this: in both cities, ZFarming is primarily located in neighborhoods with income levels that correspond to the city's median income level, rather than in low-income areas ${ }^{33,34}$.

Hence, ZFarming in developed countries is geared to the qualitative improvement of food systems rather than to securing basic food supply for low-income residents. Within the developed world, this is a major difference from ground-based urban farming. This may be due to the comparably higher obstacles faced by ZFarming implementation (see below, 'Specific implementation processes'). Even though ZFarming can only meet a very small share of the overall urban food demand and is not primarily committed to the satisfaction of basic needs, it can add to the supply of fresh and local food-especially perishable fruits and crops that usually travel a long way ${ }^{35}$.

ZFarming in the developed world meets demands of urban food movements that are largely driven by innovative pioneers and consumers. While commercial ZFarms use direct marketing strategies to sell to local consumer markets, many non-commercial farms directly involve citizens in the farming activity. Thus, we need to distinguish between 'users' who are actively involved in ZFarming as volunteers, local residents or participants in educational/social programs, and 'consumers' who buy and consume products from commercial ZFarms. An important component found in both 'users' and 'consumers' is their understanding of how the consumed goods are produced. Their behavior is determined not just by the material value but also by the cultural relevance of regional or local and organic produce ${ }^{36}$, which leads to a rising demand for regional products in many countries.

Food systems are increasingly called upon to address issues such as transparency, health, sustainability, resilience, fairness, diversity and equality ${ }^{37,38}$. ZFarming may effectively change existing structural arrangements by targeting local markets; integrating farming and food business into communities; generating local value-added goods; and establishing alternative supply chains with direct market links to consumers rather than indirect links through wholesalers or processors ${ }^{39}$.

ZFarming can contribute to local food systems, using built, social and natural urban resources. However, outcomes such as sustainability or justice depend on the goals and strategies of the actors involved ${ }^{37}$.

A critical aspect of commercial and image-oriented ZFarming is the generation of exclusionary effects and 
inequalities. Commercial ZFarms sell at high-level prices, and image-oriented ZFarms are primarily part of premium restaurants. Thus, ZFarming products are not necessarily within everyone's reach. Guthman ${ }^{40}$ points out that food activists do not necessarily relate to what residents in need of fresh food seem to want.

\section{Specific marketing strategies}

ZFarming embraces an increasing number of commercial farms that differ from many ground-based farms in their business models. A categorization of urban agriculture projects in New York reveals that the only urban farms classified as 'commercial' are rooftop farms ${ }^{20}$. These commercial ZFarms mainly address niche markets. To tap these new markets they have to use specific distribution channels and establish new alliances. Owing to their small size and, accordingly, small yields and higher unit costs as well as their explicit focus on local markets, typical distribution channels, including wholesale, are ruled out in favor of alternative supply chains without intermediaries, but with strong reliance on personal contacts and collaborations.

Collaborations may be vertical along the supply chain, e.g., with retailers, restaurants or commercial kitchens, as well as horizontal, e.g., with other farmers. Vertical collaborations with retailers are an effective way for ZFarms to open up new markets. Mid- or longterm contracts with one or more retailer(s) guarantee the purchase of a fixed amount of ZFarm produce and allow ZFarms to justify reliable revenues over several years, which in turn helps them to raise new money and expand. Retailers, in turn, can offer local, fresh produce grown in 'extraordinary' places, which may contribute to their own marketing and image. Similar arrangements exist with local restaurants. Cooperation can reach even further: Gotham Greens, a rooftop greenhouse business in New York, and Whole Foods Markets, an organic retail chain, for instance, teamed up to create a new, ecologically designed Whole Foods store with integrated rooftop greenhouse, thus further raising the visibility and transparency of local food growing.

Collaborations may also be horizontal, for example with other urban and rural producers for marketing, or with science for research and development. Offering tours, merchandising and renting farms as unique spaces for events and workshops are further ways to generate revenue. Some commercial ZFarms offer consulting for new initiatives and help to create networks among ZFarming players. According to Ackerman ${ }^{31}$, establishing networks that connect urban and rural producers with urban consumers is of particular interest. Hinrichs and Barham ${ }^{41}$ show a 'deepening and dovetailing [of] traditional producer [...] roles' by civic agriculture initiatives. This also applies to ZFarming and its specific demands: ZFarmers not only need comprehensive knowledge of farming methods that fit into built environments, but may also need marketing and distribution competences. Stevenson et al. ${ }^{17}$ note that food-related social-change groups often 'struggle for resources, technical capacity, and specific expertise. At the same time, the multiplicity and diversity of these groups provide abundant opportunities [...].'

\section{New spaces in the city}

In rural and many urban areas, land will become increasingly scarce in the future. Climate change, population pressure and soil degradation will lead to a decrease of available agricultural land, while the demand for food will continue to rise ${ }^{42}$. ZFarming does not use additional land for food production but exploits and redefines the vast potential of unused urban spaces, such as vacant buildings or rooftops. Integrating food production into the urban building stock represents an innovative way to address the issues of land scarcity and food security.

Furthermore, ZFarming offers new possibilities for architecture and urban design. The need to create green and sustainable cities and buildings is widely acknowledged by urban planners and architects ${ }^{1,6,43,44}$. By merging food production and architecture, ZFarming contributes to multifunctional buildings that offer a wide range of social and ecological benefits. According to Puri and Caplow $^{35}$, 'building-integrated agriculture is highly compatible with bioclimatic design principles, advanced by architects and environmental designers.'

Especially in dense cities with pressure on urban land markets, ZFarming can open up new spaces. While ground-based urban farming projects often face land constraints or planning insecurities (available spaces often being earmarked for development) ${ }^{11}$, many ZFarms have either long-term or unlimited leases. But ZFarms may compete with other types of use. Especially in countries with financial incentives for landlords to install roof-based solar energy systems, this might be critical ${ }^{11}$. In shrinking cities, the reuse of vacant buildings for indoor farming offers innovative solutions for redeveloping abandoned areas.

Developing multi-functional buildings with integrated farming calls for innovations in urban policies and landuse planning, particularly concerning zoning codes. Mukherji and Morales ${ }^{45}$ show how US cities have started to include urban agriculture in land-use and comprehensive planning, and established food policy planning. Some cities create specific municipal programs and organizations to assist urban farming projects by providing infrastructure, material or knowledge. Another key issue is the adjustment of urban agriculture zoning and permitting processes. There are two ways for cities to enable urban farming through zoning: either by creating a designated urban farming district or by treating urban 
farming 'as a use or a set of uses that are permitted, conditional, or forbidden, depending on the district ${ }^{45}$.

While the above-mentioned policy reactions address urban farming in general, policy frameworks and regulations also adapt to more specific ZFarming challenges, especially regarding rooftop greenhouses. Major obstacles for constructing rooftop greenhouses are zoning regulations, such as height limits and floor-to-area ratios. Rooftop greenhouses are considered additional usable space, counting toward the floor-to-area ratio in most cities. The New York Department of City Planning reacted by amending a zoning resolution to encourage educational and food production-oriented rooftop greenhouses: greenhouses that comply with certain regulations are exempt from height restrictions and floor area limitations ${ }^{20}$. The City of Boston is discussing a similar resolution. In close collaboration with different city agencies, committees and elected officials, ZFarming entrepreneurs have played a key role in pushing forward regulatory changes in New York City. However, such adjustments are still at a very early stage and cannot be extrapolated to other national settings with different planning and regulatory systems.

\section{Specific implementation processes and networks}

Depending on ZFarming forms and types, implementation processes can be rather complex, facing technical challenges and complications, such as zoning and building permits ${ }^{35}$. Germer et al. ${ }^{14}$ point out that the technical challenges of crop cultivation in buildings require interdisciplinary cooperation integrating all areas of competency. Retzlaff ${ }^{43}$ confirms that 'green buildings require the integration of various fields that normally work in separate areas of activity. In conventional development, landscape architects, architects and the construction trades often do not communicate extensively.' The innovative character of ZFarming requires interdisciplinary exchange and creates networks among actors that have not cooperated before.

This is particularly true for high-tech commercial ZFarms that often face specific challenges regarding zoning and permitting and design and construction. The analysis showed different models for initiating commercial ZFarms. One option, appropriate for ZFarms using less sophisticated technologies, is for initiators to carry out the planning and implementation process largely on their own, with external consultancy and/or voluntary support. Highly complex ZFarm planning and implementation processes, however, stress the need for a planning and management entity that involves all stakeholders, such as initiators, owners/landlords, developers, planning and engineering consultants, building businesses, investors, operators, etc. The parties involved share the (financial) risk, and benefit from an intensive exchange of experience and knowledge. However, another model implies a professionalization of the implementation process, with one 'contractor' who ideally covers the entire knowledge spectrum of ZFarm planning, implementing and operating. Collaborating with external partners, this 'contractor' could also plan and operate more than one project.

Moreover, the analysis shows that ZFarming is primarily initiated by institutions or businesses. In this, ZFarming essentially differs from ground-based urban farming, which is often started by grassroots initiatives that occupy vacant urban spaces, creatively transforming and, thus, redesigning them (often initially without an 'official' permission, although they may later be institutionalized). In ZFarming projects, such bottom-up engagement of loosely organized groups of volunteers and local residents is barely found, mainly because access to buildings and rooftop spaces always involves clear arrangements with the owners (regarding access regulations, security issues, etc.). Hence, implementing ZFarming requires a certain degree of organization and institutionalization of key players.

\section{New sources of financing}

For all urban farming initiatives, financing is an important issue, since most of them are struggling for economic viability. In the interviews, some peculiarities of ZFarming financing compared to ground-based urban farming were revealed. These concerned access to public grants and loans, support by players of the real estate market and involvement of investor equity.

These peculiarities mostly relate to large-scale commercial ZFarming. Commercial ZFarms are mainly initiated by innovative and professional start-ups that pool interdisciplinary academic and business experiences. Since these businesses are expected to tap new markets and create economic and environmental benefits, they have access to loans and grants for business development, energy efficiency, stormwater management, green roofing, etc. Furthermore, real estate developers are beginning to warm to the idea of sustainable green buildings, integrating rooftop farms and greenhouses on their own initiative and cooperating with ZFarmers - a development also driven by respective programs and incentives. For example, a landlord who seeks to install a green roof might team up with an urban rooftop farming business to apply for a grant and share the costs of co-financing. He further benefits from the alliance as the rooftop farmers will ensure the maintenance of the green roof. Thus, expanding programs for stormwater management or green buildings to ZFarming could facilitate its dissemination. However, the willingness of landlords and developers to (financially) support ZFarming also depends on the way city agencies and other controlling institutions cope with these innovative approaches and financing models, e.g., by allowing for anticipated 
revenues from a rooftop ZFarm to be incorporated into the building's pro-forma ${ }^{20}$.

\section{Conclusion}

ZFarming can be understood as a relatively young and specific form of urban farming. ZFarms act on societal needs that arise from larger local and global transformative processes that manifest themselves, especially in cities. Cities are focal points regarding the impacts of climate change, resource scarcity, urbanization and economic crisis. Consequently, action on these issues increasingly occurs on the city level - driven by local governments, local institutions, businesses, science, etc., and reinforced by the dysfunctional reactions of many national and state governments to economic and political challenges ${ }^{46,47}$. Food and urban agriculture policies are good examples of these economic and political forces. The complexity of a globalized food sector with all its implications for climate change and resource scarcity impedes efficient actions with quick results on an (inter)national level. Hence, urban food movements and farming initiatives are evolving as hands-on reactions to these societal problems, and local governments, recognizing that there is more to urban farming than just food production, respond to their demands. Urban farming offers a broad range of nonfood and non-market goods and is expected to have positive socio-cultural, economic and environmental externalities for urban societies. ZFarming, as a subtype of urban farming, represents a multifunctional landuse, combining different uses and functions within one building. It enables food production even in dense urban areas where "there is a growing need to meet a large number of societal needs on scarce urban land ${ }^{48}$. Just as the social-change activities in the agrifood system, ZFarming initiatives also vary in how strongly they challenge fundamental dimensions of dominant paradigms ${ }^{41}$. Goals range from recreational to educational and awareness building to the creation of new agrifood business models. ZFarming also implies some new dimensions compared to ground-based urban farming by: offering specific opportunities for an efficient use of local resources, particularly synergies between farming and buildings; furthering technical advancement and innovations in the building and farming sector; exploiting new urban spaces for agricultural production, but also for recreational purposes; generating new business models and marketing strategies; and requiring specific implementation and planning processes, strongly relying on local, site-specific, shared knowledge and interdisciplinary networks.

In terms of the sustainable city as an underlying planning paradigm, ZFarming can further innovations for a sustainable urban environment; contribute to the development of urban farming and urban food movements, which exhibit characteristics of social innovations; spur technical advancement and innovations for urban design and planning; and establish new business models. These innovative practices could be crucial for obtaining support by local governments struggling to restructure and reinvent their economies and to develop resourceefficient solutions for climate change mitigation and adaptation.

Further dissemination of ZFarming could be supported by: formalizing government support for urban farming including ZFarming; facilitating the integration of urban farming, including ZFarming, into the cityscape; integrating urban farming, including ZFarming, into City policies and planning ${ }^{19}$; and promoting (commercial) ZFarming as part of a new urban green economy and infrastructure. However, ZFarming is not positive per se. Potential costs and risks have to be considered, and comprehensive impacts assessments have to be made.

\section{References}

1 Giradet, H. 2008. Cities, People, Planet. Urban Development and Climate Change. Wiley, London, UK.

2 Glaeser, E. 2011. Triumph of the City: How Our Greatest Invention Makes Us Richer, Smarter, Greener, Healthier, and Happier. The Penguin Press, New York, USA.

3 Rees, W. and Wackernagel, M. 1996. Urban ecological footprints: Why cities cannot be sustainable - and why they are a key to sustainability. Environmental Impact Assessment Review 16(4-6):223-248.

4 Weber, C.L. and Matthews, H.S. 2008. Food-miles and the relative climate impacts of food choices in the United States. Environmental Science and Technology 42 (10):3508-3513.

5 Steel, C. 2012. Sitopia. Harnessing the power of food. In A. Viljoen and J.S.C. Wiskerke (eds). Sustainable Food Planning. Evolving Theory and Practice. Wageningen Academic Publishers, Wageningen, The Netherlands. p. 37-46.

6 Lehmann, S. 2010. The Principles of Green Urbanism: Transforming the City for Sustainability. Earthscan, London, UK.

7 American Planning Association (APA). 2007. Policy Guide on Community and Regional Food Planning. APA, Washington, DC, USA.

8 Pothukuchi, K. and Kaufman, J.L. 1999. Placing the food system on the urban agenda: The role of municipal institutions in food systems planning. Agriculture and Human Values 16(2):213-224.

9 Despommier, D. 2010. The Vertical Farm: Feeding the World in the 21st Century. Thomas Dunne Books, New York, USA.

10 Caplow, T. 2009. Building integrated agriculture: Philosophy and practice. In Heinrich Böll Foundation (ed.). Urban Futures 2030: Urban Development and Urban Lifestyles of the Future. Heinrich-Böll-Stiftung, Berlin, Germany. p. 54-58.

11 Specht, K., Siebert, R., Hartmann, I., Freisinger, U.B., Sawicka, M., Werner, A., Thomaier, S., Henckel, D., Walk, 
H., and Dierich, A. 2013. Urban agriculture of the future: An overview of sustainability aspects of food production in and on buildings. Agriculture and Human Values, online first, May 2013. Available at Web site http://link.springer. com/article/10.1007/s10460-013-9448-4 (verified August 14, 2013).

12 Wilson, G. 2002. Can urban rooftop microfarms be profitable? Urban Agriculture Magazine 7:22-24.

13 Nelkin, J.B. and Caplow, T. 2008. Sustainable controlled environment agriculture for urban areas. Acta Horticulturae 801:449-456.

14 Germer, J., Sauerborn, J., Asch, F., de Boer, J., Schreiber, J., Weber, G., and Müller, J. 2011. Skyfarming an ecological innovation to enhance global food security. Journal of Consumer Protection and Food Safety 6(2):237-251.

15 Wong, N.H., Tay, S.F., Wong, R., Ong, C.L., and Sia, A. 2003. Life cycle cost analysis of rooftop gardens in Singapore. Building and Environment 38:499-509.

16 The World Bank. 2013. Country and Lending Groups. Available at Web site http://data.worldbank.org/about/ country-classifications/country-and-lending-group (verified January 13, 2014).

17 Stevenson, G.W., Ruhf, K., Lezberg, S., and Clancy, K. 2007. Warrior, builder, and weaver work. Strategies for changing the food system. In C.C. Hinrichs and T.A. Lyson (eds). Remaking the North America Food System. Strategies for Sustainability. University of Nebraska Press, Lincoln and London, UK. p. 33-62.

18 Buck, D., Getz, C., and Guthman, J. 1997. From farm to table: The organic vegetable commodity chain of Northern California. Sociologia Ruralis 37:3-20.

19 Blowfield, M., Malins, A., Maynard, B., and Nelson, V. 1999. Ethical Trade and Sustainable Rural Livelihoods. Natural Resources Institute, Chatham, UK.

20 Cohen, N., Reynolds, K., and Sanghvi, R. 2012. Five Borough Farm: Seeding the Future of Urban Agriculture in New York City. Design Trust for Public Space, New York, USA.

21 Astee, L.Y. and Kishnani, N.T. 2010. Building integrated agriculture: Utilising rooftops for sustainable food crop cultivation in Singapore. Journal of Green Building 5(2):105-113.

22 Bass, B. and Baskaran, B. 2001. Evaluating Rooftop and Vertical Gardens as an Adaptation Strategy for Urban Areas. NRCC Report 46737. Institute for Research in Construction, National Research Council Canada.

23 Castleton, H.F., Stovin, V., Beck, S.B.M., and Davinson, J.B. 2010. Green roofs: Building energy savings and the potential for retrofit. Energy and Buildings 42(10):15821591.

24 Delor, M. 2011. Current State of Building-Integrated Agriculture, its Energy Benefits and Comparison with Green Roofs. University of Sheffield, Sheffield, UK.

25 Buchholz, M. 2002. Energiegewinnung, Wasseraufbereitung und Verwertung von Biomasse in Gewächshaus-GebäudeModulen (German). Technische Universität Berlin, Berlin, Germany.

26 Engelhard, B. 2010. Rooftop to tabletop: Repurposing urban roofs for food production. Masters thesis, University of Washington, Seattle, USA.

27 Graber, A., Schoenborn, A., and Junge, R. 2011. Closing water, nutrient and energy cycles within cities by urban farms for fish and vegetable production. International Water Association Newsletter 37:37-41.

28 Kloas, W., Wuertz, S., and Rennert, B. 2011. Integration of aquaculture and hydroponic into a (nearly) emission free aquaponic system assuring recycling of process water in urban farming. Presentation held at ALGAE 2011, December 2, Berlin, Germany.

29 Säumel, I., Kotsyuk, I., Hölscher, M., Lenkereit, C., Weber, F., and Kowarik, I. 2012. How healthy is urban horticulture in high traffic areas? Trace metal concentrations in vegetable crops from plantings within inner city neighbourhoods in Berlin, Germany. Environmental Pollution 165:124-132.

30 Alloway, B.J. 2004. Contamination of soils in domestic gardens and allotments: A brief overview. Land Contamination and Reclamation, 12(3):179-187.

31 Ackerman, K. 2011. The Potential for Urban Agriculture in New York City: Growing Capacity, Food Security, and Green Infrastructure. Urban Design Laboratory, Earth Institute, Columbia University, New York, USA.

32 Bryld, E. 2003. Potentials, problems, and policy implications for urban agriculture in developing countries. Agriculture and Human Values 20(1):79-86.

33 WNYC. 2013. Median income across the U.S. Available at Web site http://project.wnyc.org/median-income-nation/? \#13/40.7329/-73.9791 (verified January 13, 2014).

34 U.S. Census Bureau. 2011. American Community Survey 2011, 5-year estimates. Table B 19013 Median household income in the past 12 months (in 2012 inflation-adjusted dollars). Available at Web site http://factfinder2.census.gov/ faces/nav/jsf/pages/searchresults.xhtml?refresh=t\#none (verified January 13, 2014).

35 Puri, V. and Caplow, T. 2009. How to grow food in the $100 \%$ renewable city: Building-integrated agriculture. In P. Droege (ed.). 100\% Renewable: Energy Autonomy in Action. Earthscan, London, UK. p. 229-241.

36 Borgstedt, S. 2011. Das Paradies vor der Haustür: Die Ursprünge einer Sehnsucht aus der Perspektive soziokultureller Trendforschung (German). In C. Müller (ed.). Urban Gardening. Über die Rückkehr der Gärten in die Stadt (German). Oekom, München, Germany. p. 118-125.

37 Born, B. and Purcell, M. 2006. Avoiding the local trap: Scale and food systems in planning research. Journal of Planning Education and Research 26(2):195-207.

38 Stierand, P. 2012. Stadtentwicklung mit dem Gartenspaten. Umrisse einer Stadternährungsplanung (German). Available at Web site http://speiseraeume.de/stadternaehrungsplanung/ (verified August 14, 2013).

39 Lyson, T.A. 2007. Civic agriculture and the North American food system. In C.C. Hinrichs and T.A. Lyson (eds). Remaking the North America Food System. Strategies for Sustainability. University of Nebraska Press, Lincoln and London, UK. p. 19-32.

40 Guthman, J. 2008. Bringing good food to others: Investigating the subjects of alternative food practice. Cultural Geographies 15(4):431-447.

41 Hinrichs, C.C. and Barham, E. 2007. A full plate. Challenges and opportunities in remaking the food system. In C.C. Hinrichs and T.A. Lyson (eds). Remaking the North America Food System. Strategies for Sustainability. 
University of Nebraska Press, Lincoln and London, UK. p. 345-356.

42 Fischer, G., Hizsnyik, E., Prieler, S., and Wiberg, D. 2011. Scarcity and abundance of land resources: Competing uses and the shrinking land resource base. OLAW Background Thematic Report-TR02, FAO, Rome, Italy.

43 Retzlaff, R.C. 2009. Green buildings and building assessment systems: A new area of interest for planners. Journal of Planning Literature 24(1):3-21.

44 Berke, P.R. 2002. Does sustainable development offer a new direction for planning? Challenges for the twenty-first century. Journal of Planning Literature 17(1):21-36.
45 Mukherji, N. and Morales, A. 2010. Zoning for urban Agriculture. Zoning Practice 3. American Planning Association, Chicago, IL.

46 Katz, R. and Bradley, J. 2013. The Metropolitan Revolution. How Cities and Metropolitan Areas are Fixing Broken Politics and Fragile Economy. The Brookings Institution, Washington.

47 Barber, R.B. Dysfunctional Nations, Rising Cities. Yale University Press, New Haven and London.

48 Deelstra, T., Boyd, D., and van den Biggelaar, M. 2001. Multifunctional land use: An opportunity for promoting urban agriculture in Europe. Urban Agriculture Magazine $4: 33-35$. 